\title{
Antiinflammatory and antinociceptive activities of Blechnum occidentale L. extract
}

\author{
Fabiana Regina Nonato ${ }^{a}$, Tais Adelita Almeida Barros ${ }^{a}$, Angélica Maria Lucchese $^{b}$, \\ Carlos Eduardo Cordeiro Oliveira ${ }^{\mathrm{b}}$, Ricardo Ribeiro dos Santos ${ }^{\mathrm{a}, \mathrm{c}}$, \\ Milena Botelho Pereira Soares ${ }^{\mathrm{a}, \mathrm{c}}$, Cristiane Flora Villarreal ${ }^{\mathrm{a}, \mathrm{d}, *}$ \\ a Centro de Pesquisas Gonçalo Moniz, Fundação Oswaldo Cruz, Rua Waldemar Falcão 121, CEP 40296-710 Salvador, Bahia, Brazil \\ ${ }^{\mathrm{b}}$ Laboratório de Química de Produtos Naturais e Bioativos, Departamento de Ciências Exatas, Universidade Estadual de Feira de Santana, \\ Avenida Transnordestina s/n, CEP 44036-900 Feira de Santana, Bahia, Brazil \\ ${ }^{\mathrm{c}}$ Hospital São Rafael, Av. São Rafael 2152, CEP 41253-190 Salvador, Bahia, Brazil

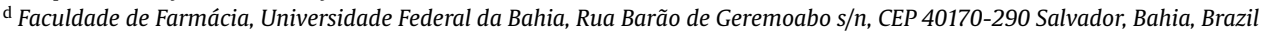

\section{A R T I C L E I N F O}

\section{Article history:}

Received 5 March 2009

Received in revised form 29 May 2009

Accepted 5 June 2009

Available online 12 June 2009

\section{Keywords:}

Blechnum

Pteridophyte

Antinociception

Antiinflammatory

Biological activity

\begin{abstract}
A B S T R A C T
Aim of study: Blechnum occidentale L. is a terrestrial fern that ranges from the United States to South America, and is employed in Brazilian folk medicine. In the present study we investigated the antinociceptive and antiinflammatory activities of the methanolic extract of Blechnum occidentale L. (MEB) in animal models of pain and inflammation to support its medicinal use in treatment of inflammatory and pulmonary diseases, urinary infections and liver diseases.

Materials and methods: The antinociceptive activity of MEB was evaluated using the writhing, formalin, and tail flick tests. The antiinflammatory activity of MEB was evaluated in carrageenan-induced paw oedema and neutrophil migration. In order to discard possible non-specific muscle relaxant or sedative effects of MEB, mice motor performance was evaluated in the rota rod test and its toxicity evaluated over 14 days.

Results: Intraperitoneal (IP) administration of MEB $(0.01-100 \mathrm{mg} / \mathrm{kg})$ produced a dose-related antinociception on acetic acid-induced writhing in mice. Oral administration of MEB, at a different range of doses $(100-400 \mathrm{mg} / \mathrm{kg}$ ), also produced significant antinociceptive effect on the writhing test. Furthermore, treatment with MEB (100 and $200 \mathrm{mg} / \mathrm{kg}$ IP) inhibited significantly both the early and late phases of formalin-induced hypernociception in rats. In contrast, treatment with MEB ( 100 and $200 \mathrm{mg} / \mathrm{kg}$ IP) did not prevent the thermal nociception in the tail flick test. The IP administration of MEB $(100$ and $300 \mathrm{mg} / \mathrm{kg})$ significantly reduced the paw oedema induced by carrageenan. Moreover, systemic treatment with MEB $(11-300 \mathrm{mg} / \mathrm{kg}$ ) reduced the neutrophil migration in the carrageenan-induced migration to the peritoneal cavity. In the rota rod test, MEB-treated mice did not show any significant motor performance alterations with the dose of $300 \mathrm{mg} / \mathrm{kg}$. In addition, over the study duration of 14 days, there were no deaths or toxic signs recorded in the mice given 100 or $1000 \mathrm{mg} / \mathrm{kg}$ of MEB.

Conclusion: The results described here are the first report of pharmacological studies of Blechnum occidentale $\mathrm{L}$. and indicate that this plant has antinociceptive and antiinflammatory activities which support its folk medicine use.
\end{abstract}

(c) 2009 Elsevier Ireland Ltd. All rights reserved.

\section{Introduction}

The clinical treatment of inflammatory diseases is dependent on nonsteroidal or steroidal chemical therapeutics (Rainsford,

\footnotetext{
* Corresponding author at: Laboratório de Engenharia Tecidual e Imunofarmacologia, Centro de Pesquisa Gonçalo Moniz, Fundação Oswaldo Cruz, Waldemar Falcão 121 Candeal, CEP 40296-710 Salvador, BA, Brazil. Tel.: +55 71 31762260; fax: +55 7131762327 .

E-mail address: cfv@ufba.br (C.F. Villarreal).
}

2007). Nonsteroidal antiinflammatory drugs (NSAID) reduce the pain and inflammation by blocking the metabolism of arachidonic acid by cyclooxygenase enzyme (COX), and thereby the production of prostaglandin (Vane, 1971). Since prostaglandins are cytoprotective, long-term administration of NSAID may induce gastro-intestinal ulcers, bleeding, and renal disorders due to their non-selective inhibition of both isoforms of the COX enzyme, the constitutive (COX-1) and the inducible (COX-2) isoforms (Robert, 1976; Peskar, 1977; Tapiero et al., 2002). On the other hand, fully selective and reversible COX-2 inhibitors with reduced gastro-intestinal toxicity have been associated with adverse car- 
diovascular effects (Dogné et al., 2005). Furthermore, the use of steroidal drugs as antiinflammatory agents is also becoming highly controversial due to their multiple side effects (Schäcke et al., 2002; Reinke et al., 2002). Therefore, developing new agents with more powerful analgesic and antiinflammatory activities and with lesser side effects is, at present, of great interest.

Since ancient times, pteridophytes have been considered an excellent source of medicines, as Dioscorides and Galeno stated in their manuscripts (Barros and Andrade, 1997), and have been used to treat different types of pain (Cambie and Ash, 1994; Christensen, 1997; Gogoi, 2002; Bresciani et al., 2003). Some species of Blechnum, an example of pteridophyte genus, are employed in folk medicine worldwide. Blechnum occidentale L. is a terrestrial and/or rupestrial fern that ranges from the United States to South America, including Colombia, Venezuela, Guayanas, Ecuador, Peru, Bolivia, Brazil, Paraguay, Chile, and Argentina (Moran, 1995). In Brazil this fern has been used to treat inflammatory and pulmonary diseases, urinary infections and liver diseases (Barros and Andrade, 1997). However, few works about pteridophyte medicinal properties have been reported, especially in oriental countries where traditional medicine employs many species of herbs and is largely used by a large number of people. In fact, to the best of our knowledge, this is the first report of pharmacological studies of Blechnum occidentale L. As part of our continuous interest in Brazilian native plants and in order to support the use of this fern in folk medicine, the present study was undertaken to establish the antiinflammatory and antinociceptive properties of the methanolic extract of Blechnum occidentale L. (MEB). In addition, we evaluated acute toxicity and motor performance alterations associated with MEB.

\section{Materials and methods}

\subsection{Plant material}

Plant specimens were collected in the Atlantic Forest region at Salvador, Bahia State, Brazil, in August, 2006, in authorized areas by IBAMA (Brazilian Institute for the Environment and Natural Resources) and received botanic identification by Dr. Fabiana R. Nonato. A voucher specimen has been deposited at the Herbarium of Universidade Estadual de Feira de Santana, Bahia, Brazil (HUEFS 142950).

\subsection{Preparation of the methanolic extract}

The air-dried and powdered blades of Blechnum occidentale $(37.6 \mathrm{~g})$ were exhaustively extracted with methanol. The obtained extracts were filtered and evaporated under reduced pressure, on a rotary evaporator at $40-45^{\circ} \mathrm{C}$, to yield $5.6 \mathrm{~g}(15 \%, \mathrm{w} / \mathrm{w})$ of crude methanolic extract.

\subsection{Animals}

Experiments were performed on male Wistar rats (180-200 g) or Swiss Webster mice (30-35 g) from the Animal Facilities of Centro de Pesquisas Gonçalo Moniz. Animals, individually housed at $24 \pm 1^{\circ} \mathrm{C}$, under a 12:12 h light-dark cycle (lights on at 07:00 a.m.), with free access to chow and tap water until the day of the experiment, when only water was made available to them. Each animal was used only once. Animal care and handling procedures were in accordance with International Association for the Study of Pain guidelines for the use of animals in pain research (Zimmermann, 1983) and Institutional Animal Care and Use Committee - FIOCRUZ 26/2009-1.
All efforts were made to minimize the number of animals used and any discomfort. All behavioral testing was performed between 8:00 a.m. and 4:00 p.m.

\subsection{Nociceptive tests}

In the present study we used the term hypernociception rather than hyperalgesia or allodynia to define the decrease in the nociceptive withdrawal threshold, since the pain perception in animals is not obvious.

\subsubsection{Writhing test}

The intraperitoneal and oral antinociceptive doses of MEB were determined in mice using the writhing test. Acetic acid $(0.8 \%, \mathrm{v} / \mathrm{v}$, $10 \mathrm{ml} / \mathrm{kg}$ ) was injected into the peritoneal cavities of mice, which were placed in a large glass cylinder and the intensity of nociceptive behavior was quantified by counting the total number of writhes occurring between 0 and 30 min after the stimulus injection (Collier et al., 1968). The writhing response consists of a contraction of the abdominal muscle together with a stretching of the hind limbs. The antinociceptive activity was expressed as the writhing scores over $30 \mathrm{~min}$.

\subsubsection{Formalin test}

Rats were placed in an open Plexiglas observation chamber for $30 \mathrm{~min}$ to accommodate to their surroundings, and then removed for formalin administration. Rats were gently restrained while the dorsum of the hind paw was subcutaneously administered with $50 \mu \mathrm{l}$ of formalin $1 \%$ (1:100 dilution of stock formalin solution, $37 \%$ formaldehyde in $0.9 \%$ saline) using a 30 gauge needle. Following injection, the rat was returned to the observation chamber for a 60 min observation period. A mirror was placed behind the chamber to enable unhindered observation of the formalin-injected paw. Rats were observed from 0 to $10 \mathrm{~min}$ (early phase) and from 15 to $60 \mathrm{~min}$ (late phase) and a nociception score was determined for each period by counting the number of flinches of the injected limb during the observation time (Dubuisson and Dennis, 1977). Flinches were discrete and easily quantifiable.

\subsubsection{Tail flick test}

The tail flick test (Analgesiometer, Insight, Brazil) in rats was conducted as described elsewhere (D'Amour and Smith, 1941), with minor modifications. Each animal was placed in a ventilated tube with the tail laid across a wire coil which was at room temperature $\left(23 \pm 2{ }^{\circ} \mathrm{C}\right)$. The coil temperature was then raised by the passage of electric current and the latency for the tail withdrawal reflex was measured. The heating was applied to a portion of the ventral surface of the tail $4 \mathrm{~cm}$ from the tip. Each trial was terminated after $6 s$ to minimize the probability of skin damage. Tail flick latency was measured before and 40 min after the MEB or saline administration.

\subsection{Paw oedema induced by carrageenan}

The volume of the mice paw was measured with a plesthismometer (Ugo Basile, Comerio, Italy) before ( $\mathrm{bb}$, baseline) the intraplantar administration of carrageenan $(200 \mu \mathrm{g})$ and 2, 4, 24 and $48 \mathrm{~h}$ after (Vt), as described previously (Winter et al., 1962). The amount of paw swelling was determined for each mouse and the difference between $\mathrm{Vt}$ and $\mathrm{Vb}$ was taken as the oedema value.

\subsection{Leukocyte migration}

The leukocyte migration test in mice was conducted as described elsewhere (Ramos et al., 2005). Carrageenan ( $2 \mathrm{mg} /$ cavity) was injected into the peritoneal cavities in mice, and leukocyte migration was evaluated $4 \mathrm{~h}$ after stimulus. The animals were sacrificed, 
and the peritoneal cavity cells were harvested with $3 \mathrm{ml}$ PBS containing 1 mM EDTA. Total cell counts were performed in a Neubauer chamber and differential cell counts ( 100 total cells) were obtained using panotic-stained cytospin preparations. The differential count was performed under light microscope, and the results were presented as number of neutrophils per cavity, according to standard morphological criteria. The results were expressed as the number of neutrophils/cavity.

\subsection{Acute toxicity}

The method described by Lorke (1983) with slight modification was used to determine the safety of the MEB. Briefly, normal healthy male mice were divided into groups of five mice in each cage. MEB (100 and $1000 \mathrm{mg} / \mathrm{kg}$ ) or vehicle was intraperitoneally administered. Access to food and water, toxic symptoms and the general behavior of mice were observed continuously for $1 \mathrm{~h}$ after the treatment and then intermittently for $4 \mathrm{~h}$, and thereafter over a period of $24 \mathrm{~h}$. The mice were further observed for up to 14 days following treatment for any signs of toxicity and mortality.

\subsection{Motor function assay: rota rod}

To evaluate the possible non-specific muscle-relaxant or sedative effects of MEB, mice were submitted to the rota rod task (Vaz et al., 1996). Rota rod apparatus (Insight, Ribeirão Preto, Brazil) consisted of a bar with a diameter of $3 \mathrm{~cm}$, subdivided into four compartments. The bar rotated at a constant speed of five revolutions per minute. The animals were selected $24 \mathrm{~h}$ previously by eliminating those mice which did not remain on the bar for two consecutive periods of $120 \mathrm{~s}$. Animals were treated with Diazepan $(10 \mathrm{mg} / \mathrm{kg}$ IP), MEB (200 mg/kg IP) or vehicle and $30 \mathrm{~min}$ after were placed on a rotating rod. The latency to falling was measured up to $120 \mathrm{~s}$. The results are expressed as the average time(s) the animals remained on the rota rod in each group.

\subsection{Drugs}

Indomethacin, dexamethasone and carrageenan were obtained from Sigma Chemical Company (St. Louis, MO, USA). Diazepam was obtained from Cristália (Itapira, São Paulo, Brazil). Indomethacin was dissolved in Tris- $\mathrm{HCl} 0.1 \mathrm{M} \mathrm{pH} 8.0$ plus saline. Dexamethasone $(1 \mathrm{mg} / \mathrm{ml})$ was dissolved in ethanol (10\% in normal saline). Remaining drugs and MEB were dissolved directly in saline. The drugs were administrated by oral (PO), intraperitoneal (IP) or subcutaneous (SC) routes.

\subsection{Data analysis}

Data are presented as means \pm SEM of measurements made on five animals in each group. Comparisons across three or more treatments were made using one-way ANOVA with Tukey's post hoc test or repeated measures two-way ANOVA with Bonferroni's post hoc test, when appropriate. All data were analyzed using the Prism 4 computer software (GraphPad, San Diego, USA). Statistical differences were considered to be significant at $P<0.05$.

\section{Results}

\subsection{Antinociceptive effect of MEB}

The antinociceptive activity of MEB was evaluated by using the writhing test. Intraperitoneal administration of MEB $(0.01-100 \mathrm{mg} / \mathrm{kg}), 30 \mathrm{~min}$ before the acid injection, produced a significant $(P<0.01)$ and dose-related inhibition of acetic acid-induced abdominal constrictions in mice (Fig. 1A). Indomethacin $(10 \mathrm{mg} / \mathrm{kg}$
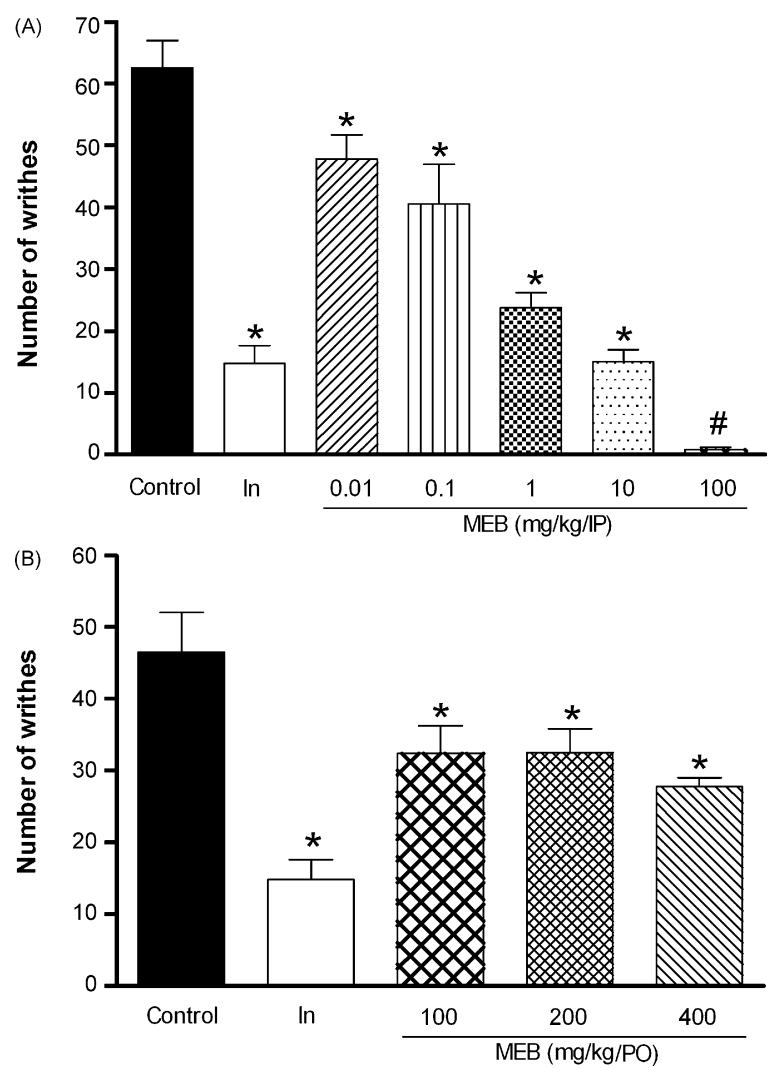

Fig. 1. Effects of oral or intraperitoneal administration of Blechnum occidentale L. methanolic extract (MEB) on acetic acid-induced writhing in mice. (A) Mice were treated with MEB $(0.01,0.1,1,10$ and $100 \mathrm{mg} / \mathrm{kg}$ ) or control (saline) by intraperitoneal route $30 \mathrm{~min}$ before acetic acid $0.8 \%$ (injected at time zero). (B) Mice were orally treated with MEB (100, 200 and $400 \mathrm{mg} / \mathrm{kg}$ ) or saline (control group) $40 \mathrm{~min}$ before acetic acid $0.8 \%$. Indomethacin (In; $10 \mathrm{mg} / \mathrm{kg}$ IP) was the reference drug. Data are expressed as means \pm S.E.M.; $n=5$ mice per group. *Significantly different from control group; " significantly different from the remaining groups $(P<0.05)$ as determined by ANOVA followed by Tukey's test.

IP), a standard NSAID used as positive control, also produced significant inhibition of acetic acid-induced writhing response. Moreover, oral administration of MEB (100-400 mg/kg), 40 min before the acid injection, produced a significant $(P<0.05)$ inhibition of acetic acidinduced abdominal constrictions in mice (Fig. 1B). Fig. 2 shows the effect of MEB on the formalin-induced hypernociception in rats. Injection of formalin in control animals induced a biphasic flinching response, with the early phase ranging from 0 to $10 \mathrm{~min}$ (Fig. 2A) and the late phase from 15 to 60 min (Fig. 2B) after the injection. Treatment with MEB (100 and $200 \mathrm{mg} / \mathrm{kg}$ ) by intraperitoneal route $30 \mathrm{~min}$ before the formalin caused a antinociceptive effect $(P<0.001)$ in both the early and late phases of formalin-induced hypernociception in rats. Indomethacin $(5 \mathrm{mg} / \mathrm{kg} \mathrm{IP})$ produced a significant $(P<0.001)$ antinociceptive effect in rats submitted to the formalin test. In a different way, MEB (100 and $200 \mathrm{mg} / \mathrm{kg}$ IP) did not alter the latency response to the tail flick test. In contrast, morphine ( $5 \mathrm{mg} / \mathrm{kg} \mathrm{SC}$ ) caused a significant increase in the latency response (data not shown).

\subsection{Antiinflammatory effects of MEB}

The antiinflammatory effects of MEB were initially evaluated in the paw oedema model in mice. The results in Fig. $3 \mathrm{~A}$ indicate that the administration of MEB ( 100 and $300 \mathrm{mg} / \mathrm{kg}$ IP) $30 \mathrm{~min}$ before carrageenan reduced significantly $(P<0.01)$ the oedema at $2,4,24$ and $48 \mathrm{~h}$ after the carrageenan injection. Furthermore, the administration of MEB at the same doses $4 \mathrm{~h}$ before car- 

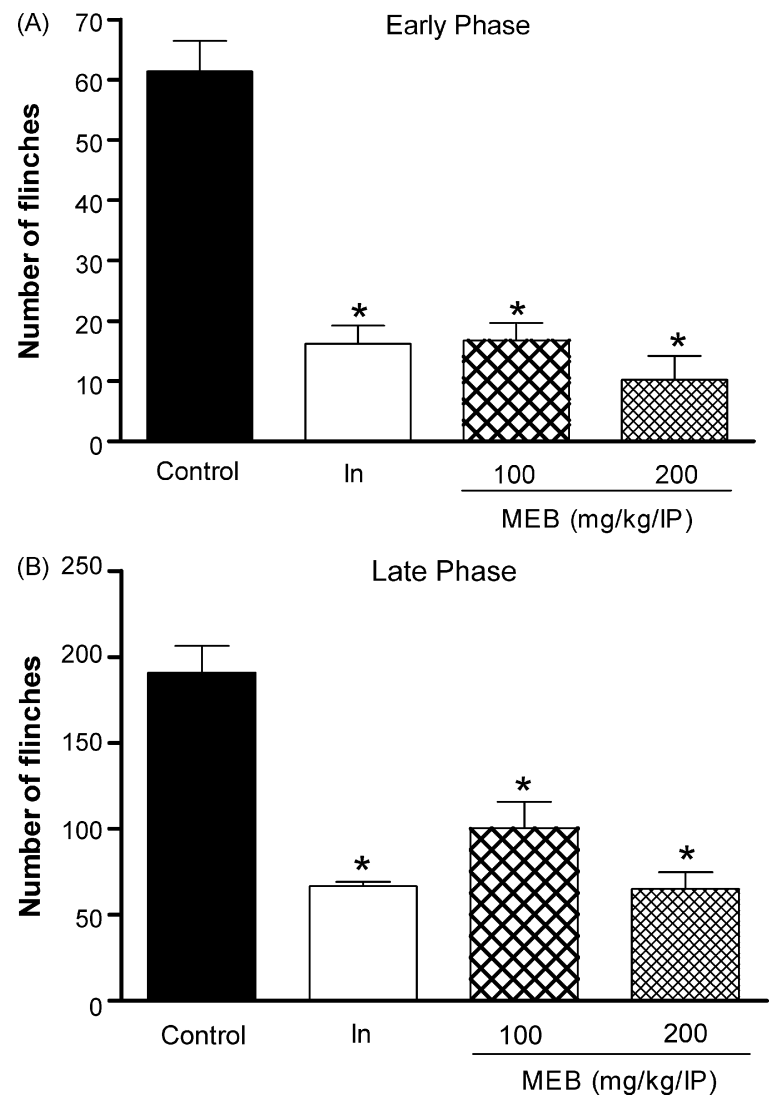

Fig. 2. Effects of Blechnum occidentale L. methanolic extract (MEB) treatment on inflammatory pain induced by formalin in rats. Inflammatory pain was induced by subcutaneous intraplantar injection of formalin $1 \%(50 \mu \mathrm{l})$. (A and B) Effects of MEB on the early and late phases of formalin-induced flinches in rats, respectively. Wistar rats were treated with MEB $(100$ and $200 \mathrm{mg} / \mathrm{kg}$ ) or saline (control group) by intraperitoneal administration $30 \mathrm{~min}$ before formalin (injected at time zero). Indomethacin (In; $5 \mathrm{mg} / \mathrm{kg} \mathrm{IP}$ ) was the reference drug. Data are expressed as means \pm S.E.M.; $n=5$ mice per group. *Significantly different from control group $(P<0.05)$ as determined by ANOVA followed by Tukey's test.

rageenan also reduced significantly $(P<0.01)$ the oedema 2,4 and $24 \mathrm{~h}$, but not $48 \mathrm{~h}$ after the carrageenan injection (Fig. 3B). The oedema induced by intraplantar injection of carrageenan in mice was strongly inhibited at $2,4,24$ and $48 \mathrm{~h}$ by pre-treatment $(4 \mathrm{~h}$ before) with dexamethasone $(0.7 \mathrm{mg} / \mathrm{kg} \mathrm{SC})$. MEB was also capable of reducing the neutrophil migration in the carrageenan-induced

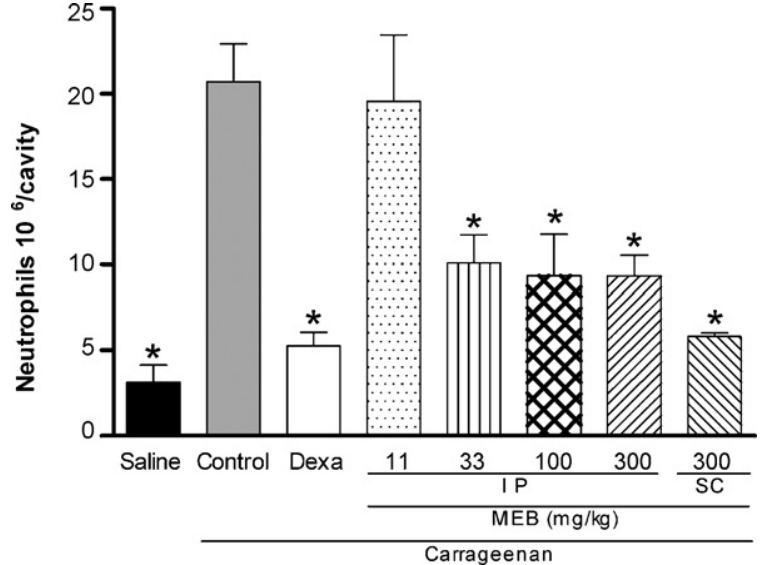

Fig. 4. Effects of Blechnum occidentale L. methanolic extract (MEB) treatment on carrageenan-induced neutrophil migration to peritoneal cavity. Mice were treated with MEB (11, 33, 100 and $300 \mathrm{mg} / \mathrm{kg}$ IP), MEB (300 mg/kg SC), dexamethasone $(0.7 \mathrm{mg} / \mathrm{kg} \mathrm{SC}$ ) or saline (control group) $4 \mathrm{~h}$ before carrageenan ( $2 \mathrm{mg} /$ cavity) intraperitoneal stimulus. Peritoneal exudates were collected $4 \mathrm{~h}$ after carrageenan. Total counts were performed with a cell counter and differential cell counts were carried out on light microscope. Results are expressed as means \pm S.E.M. of number of neutrophil $10^{6} /$ cavity $(n=5)$. *Significantly different from control group $(P<0.01)$ as determined by ANOVA followed by Tukey's test.

neutrophil migration to the peritoneal cavity (Fig. 4). Mice were treated with MEB $(11,33,100,300 \mathrm{mg} / \mathrm{kg}$ IP and $300 \mathrm{mg} / \mathrm{kg} \mathrm{SC}$ ) or dexamethasone $(0.7 \mathrm{mg} / \mathrm{kg} \mathrm{SC}) 4 \mathrm{~h}$ before the intraperitoneal injection of carrageenan ( $2 \mathrm{mg} /$ cavity). The neutrophil migration to the peritoneal cavity was evaluated $4 \mathrm{~h}$ after carrageenan. MEB, as well as the reference drug dexamethasone, significantly inhibited the carrageenan-induced neutrophil migration $(P<0.01)$.

\subsection{Acute toxicity of $M E B$}

Over the study duration of 14 days, there were no deaths recorded in the groups of mice given 100 or $1000 \mathrm{mg} / \mathrm{kg}$ IP of MEB. During the observation period, MEB administration did not produce any variations in the general appearance or toxic signs in the animals.

\subsection{Effect of MEB in the motor performance}

In the rota rod test, MEB-treated mice did not show any significant motor performance alterations with the dose of $300 \mathrm{mg} / \mathrm{kg}$ IP

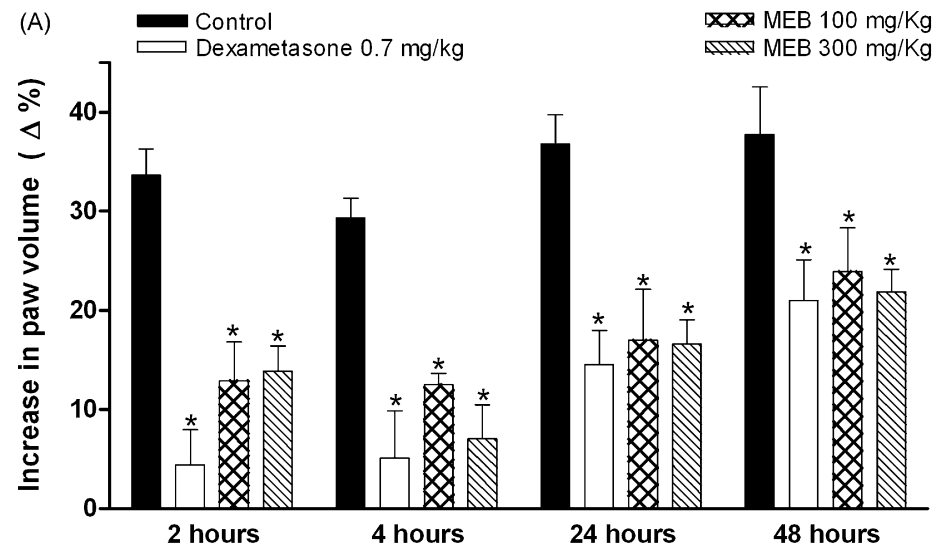

(B)

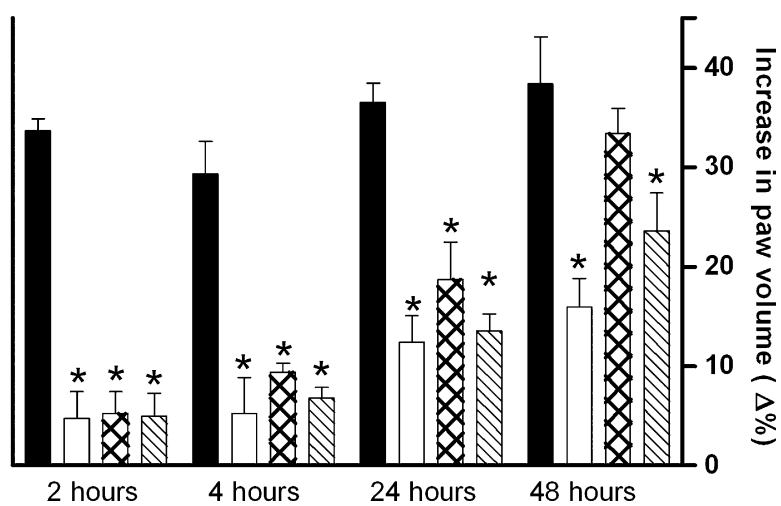

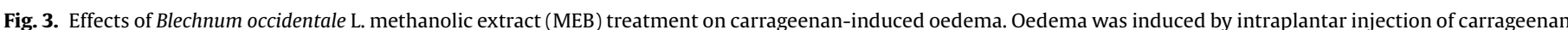

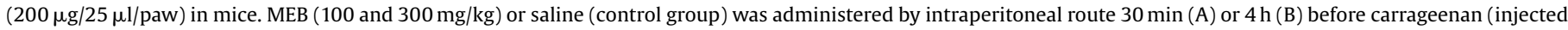

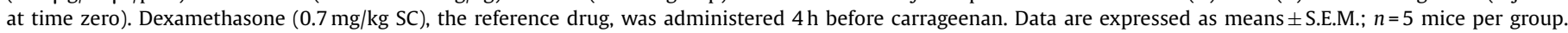
*Significantly different from control group $(P<0.05)$ as determined by two-way ANOVA followed by Bonferroni's test. 
$(113.7 \pm 6.3 \mathrm{~s})$ if compared to control $(105.4 \pm 8.1 \mathrm{~s})$. As expected, the central nervous system depressant diazepam $(10 \mathrm{mg} / \mathrm{kg}$ IP) reduced the time of mice on the rota rod after 30 min of treatment with this standard drug $(6.1 \pm 1.9 \mathrm{~s})$.

\section{Discussion}

The purpose of this work was to establish the scientific basis for the folk use of Blechnum occidentale L. The present study demonstrates, for the first time, that systemic administration of the MEB, at doses that did not produce any motor performance alteration, produced consistent antinociceptive and antiinflammatory effects in different models of pain and inflammation. The antinociceptive effect of MEB was observed in acetic acid-induced writhing and formalin tests, but not in the tail flick test. Moreover, MEB produced antiinflammatory effect on carrageenan-induced paw oedema and neutrophil migration.

Intraperitoneal administration of MEB produced a dose-related antinociception when assessed in acetic acid-induced writhing in mice. Oral administration of MEB was less potent and efficacious than its intraperitoneal administration in preventing the nociception induced by acetic acid. In fact, the bioavailability of active substances may be decreased when given orally, due to the instability in gastric and intestinal fluids and/or poor absorption in the gastro-intestinal tract (Kofi-Tsekpo, 1994). The writhing test has long been used as a screening tool for the assessment of analgesic or antiinflammatory properties of new substances (Collier et al., 1968). This method presents a good sensitivity; however, it shows poor specificity. To avoid misinterpretation of the results, in the present study we confirmed the antinociceptive effect of MEB in a model of inflammatory pain, the formalin test, which has two distinctive phases that can possibly indicate different types of pain (Hunskaar and Hole, 1987). The early and late phases of formalin test have obvious differential properties, and therefore this test is useful not only for assessing the analgesic substances but also for elucidating the mechanism of analgesia (Shibata et al., 1989). The early phase, named non-inflammatory pain, is a result of direct stimulation of nociceptors and reflects centrally mediated pain; the late phase, named inflammatory pain, is caused by local inflammation with a release of inflammatory and hyperalgesic mediators (Hunskaar and Hole, 1987). In the present study we found that MEB produced antinociceptive activity both in the early and late phases of formalin test. Considering the inhibitory property of MEB on the second phase of formalin, we suggest that its antinociceptive activity is due, at least in part, to an antiinflammatory action. In line with this idea, the treatment with MEB did not prevent the nociception in the tail flick test. The thermal model of the tail flick test is considered to be a spinal reflex, but could also involve higher neural structures and this method identifies mainly central analgesics (Jensen and Yaksh, 1986; Le Bars et al., 2001). The fact that MEB produced antinociception in all nociceptive models tested, except in the tail flick test, suggests that it does not block the neural transmission of pain, like morphine does. Moreover, disproving relaxing or motor deficit effects, MEB treatment, at the therapeutic doses, did not affect the motor performance of the mice as tested in the rota rod test. This result corroborates the antinociceptive effect of MEB suggested by the nociceptive tests.

With the goal of proving the antiinflammatory property of MEB, we evaluated the effects of MEB treatment on the carrageenaninduced paw oedema in mice. This method was chosen for this study since it is the most prominent experimental model in search for new antiinflammatory drugs and evaluation of antiinflammatory effect of natural products (Sugishita et al., 1981; Posadas et al., 2004; Asres et al., 2005). We found that the administration of MEB reduced significantly the carrageenan-induced paw oedema.
This result reinforces the idea that the MEB possesses peripheral action, probably related to the arachidonic acid cascade (Le Bars et al., 2001). The injection of carrageenan in mice produces a typical biphasic oedema associated with the production of several inflammatory mediators such as histamine, serotonin, bradykinin, prostaglandins, nitric oxide, and cytokines (Levy, 1969; Di Rosa et al., 1971; Vinger et al., 1987; Henriques et al., 1987; Nantel et al., 1999; Posadas et al., 2004; Rocha et al., 2006). It has been demonstrated that a different profile of inflammatory mediators involved with the first and second phases of the carrageenan-induced paw oedema in mice. Siqueira-Junior et al. (2003) demonstrated that treatment with the COX-1 inhibitor reduced of the early phase of paw oedema. Moreover, COX-2 is up-regulated only in the second phase (Posadas et al., 2004). Conversely, it has been shown that nitric oxide and TNF-alpha are implicated in the two phases of carrageenan-evoked mouse paw oedema (Posadas et al., 2004; Bucci et al., 2005; Rocha et al., 2006). According to the result of our study, MEB was able to effectively inhibit the oedema in both the earlier and in the later phases, suggesting that MEB inhibits different chemical mediators of inflammation. In addition, as these effects are the result of a single administration of the extract, it is possible that a relatively long-lasting antiinflammatory action of MEB. We also found that the full antiinflammatory effect of MEB was observed $4 \mathrm{~h}$ after its administration. This delayed antiinflammatory effect could indicate that it is dependent on the modulation of transcriptional factors and de novo synthesis of proteins involved in the inflammatory response. In fact, the major therapeutic effects of glucocorticoids, the most clinically used antiinflammatory drugs, are dependent on the interaction with responsive genes, which ultimately lead to the inhibition of pro-inflammatory protein transcription (Barnes, 2006). Confirming the relevant antiinflammatory activity of MEB we observed that the neutrophil migration to peritoneal cavity was strongly reduced by the extract. The cell migration inhibition in models of inflammation has been considerate a convincing indicator of antiinflammatory activity (Bradley et al., 1982; Faurschou and Borregaard, 2003).

Taken together, the results presented herein strongly suggest that Blechnum occidentale L. possesses analgesic and antiinflammatory effects, supporting the use of this plant species in folk medicine. Furthermore, the acute toxicity does not show any symptoms, changes in behavior or mortality at $1 \mathrm{~g} / \mathrm{kg}$ doses that indicate a therapeutic safety for the doses pharmacologically active. The precise mechanisms through which MEB exerts its action are currently under investigation, but possibly it could be related to the arachidonic acid cascade and/or modulation of pro-inflammatory molecules production.

\section{Acknowledgements}

This work was supported by CNPq, FAPESB, IMSEAR, RENORBIO, FINEP, MCT and FIOCRUZ.

\section{References}

Asres, K., Gibbons, S., Hana, E., Bucar, F., 2005. Anti-inflammatory activity of extracts and a saponin isolated from Melilotus elegans. Die Pharmazie 60, 310-312.

Barnes, P.J., 2006. How corticosteroids control inflammation: quintiles prize lecture 2005. British Journal of Pharmacology 148, 245-254.

Barros, I.C.L., Andrade, L.H.C. 1997. Pteridófitas medicinais (samambaias, avencas e plantas afins). Universitária da Universidade Federal de Pernambuco, Recife.

Bradley, P.P., Priebat, D.A., Christensen, R.D., Rothstein, G., 1982. Measurement of cutaneous inflammation: estimation of neutrophil content with an enzyme marker. The Journal of Investigative Dermatology 78, 206-209.

Bresciani, L.F., Priebe, J.P., Yunes, R.A., Dal Magro, J., Delle Monache, F., de Campos, F. de Souza, M.M., Cechinel-Filho, V., 2003. Pharmacological and phytochemical evaluation of Adiantum ceneatum growing in Brazil. Zeitschrift für Naturforschung. C. Journal of Biosciences 58, 191-194.

Bucci, M., Roviezzo, F., Posadas, I., Yu, J., Parente, L., Sessa, W.C., Ignarro, L.J., Cirino, G., 2005. Endothelial nitric oxide synthase activation is critical for vascular leak- 
age during acute inflammation in vivo. Proceedings of the National Academy of Sciences of the United States of America 102, 904-908.

Cambie, R.C., Ash, J., 1994. Fijian Medicinal Plants. Commonwealth Scientific and Industrial Research Organisation, Melbourne.

Christensen, H., 1997. Uses of ferns in two indigenous communities in Sarawak, Malaysia. In: Johns, R.J. (Ed.), Holttum Memorial Volume. Royal Botanic Gardens, Kew, pp. 177-192.

Collier, H.O., Dinneen, L.C., Johnson, C.A., Schneider, C., 1968. The abdominal constriction response and its suppression by analgesic drugs in the mouse. British Journal of Pharmacology and Chemotherapy 32, 295-310.

D'Amour, F.E., Smith, D.L., 1941. A method for determining loss of pain sensation. The Journal of Pharmacology and Experimental Therapeutics 72, 74-79.

Di Rosa, M., Giroud, J.P., Willoughby, D.A., 1971. Studies on the mediators of the acute inflammatory response induced in rats in different sites by carrageenan and turpentine. The Journal of Pathology 104, 15-29.

Dogné, J.M., Supuran, C.T., Pratico, D., 2005. Adverse cardiovascular effects of the coxibs. Journal of Medicinal Chemistry 48, 2251-2257.

Dubuisson, D., Dennis, S.G., 1977. The formalin test: a quantitative study of the analgesic effects of morphine, meperidine and brain-stem stimulation in rats and cats. Pain 4, 161-174.

Faurschou, M., Borregaard, N., 2003. Neutrophil granules and secretory vesicles in inflammation. Microbes and Infection/Institut Pasteur 5, 1317-1327.

Gogoi, R., 2002. Ethnobotanical studies of some ferns used by the Garo Tribals of Meghalaya. Advances in Plant Sciences 15, 401-405.

Henriques, M.G.M.O., Silva, PM.R., Martins, M.A., Flores, C.A., Cunha, F.Q., AssreuyFilho, J., Cordeiro, R.S.B., 1987. Mouse paw oedema. A new model for inflammation? Brazilian Journal of Medical and Biological Research 20, 243-249.

Hunskaar, S., Hole, K., 1987. The formalin test in mice: dissociation between inflammatory and non-inflammatory pain. Pain 30, 103-114

Jensen, T.S., Yaksh, T.L., 1986. Comparison of antinociceptive action of morphine in the periaqueductal gray, medial and paramedial in rat. Brain Research 363, 99-113.

Kofi-Tsekpo, M.W., 1994. Optimization of pharmaceutical formulations for therapy. African Journal of Health Sciences 1, 13-19.

Le Bars, D., Gozariu, M., Cadden, S., 2001. Animal models of nociception. Pharmacological Reviews 53, 628-651.

Levy, L., 1969. Carrageenan paw edema in the mouse. Life Sciences 8, 601-606.

Lorke, D., 1983. A new approach to practical acute toxicity testing. Archives of Toxicology 54, 275-287.

Moran, R.C., 1995. Blechnaceae. In: Psilotaceae a Salviniaceae, In: Moran, R.C., Riba, R. (Eds.), Flora Mesoamericana, vol. 1. Universidad Nacional Autónoma de México, México, pp. 325-333.

Nantel, F., Denis, D., Gordon, R., Northey, A., Cirino, M., Metters, K.M., Chan, C.C. 1999. Distribution and regulation of cyclooxygenase- 2 in carrageenan-induced inflammation. British Journal of Pharmacology 128, 853-859.

Peskar, B.M., 1977. On the synthesis of prostaglandins by human gastric mucosa and its modification by drugs. Biochimica et Biophysica Acta 487, 307-314.
Posadas, I., Bucci, M., Roviezzo, F., Rossi, A., Parente, L., Sautebin, L., Cirino, G., 2004. Carrageenan-induced mouse paw oedema is biphasic, age-weight dependent and displays differential nitric oxide cyclooxygenase-2 expression. British Journal of Pharmacology 142, 331-338.

Rainsford, K.D., 2007. Anti-inflammatory drugs in the 21st century. Sub-cellular Biochemistry 42, 3-27.

Ramos, C.D.L., Canetti, C., Souto, J.T., Silva, J.S., Hogaboamá, C.M., Ferreira, S.H. Cunha, F.Q., 2005. MIP- $1 \alpha[C C L 3]$ acting on the CCR1 receptor mediates neutrophil migration in immune inflammation via sequential release of TNF- $\alpha$ and LTB $_{4}$. Journal of Leukocyte Biology 78, 167-177.

Reinke, P., Bevilacqua, M., Tryon, V., Cheronis, J., Volk, H.D., 2002. Immune monitoring of glucocorticoid therapy. In: Ernst Schering Research Foundation Workshop, vol. 40 , pp. 25-37.

Robert, A., 1976. Antisecretory, antiulcer, cytoprotective and diarrheogenic properties of prostaglandins. Advances in Prostaglandin and Thromboxane Research 2 507-520.

Rocha, A.C.C., Fernandes, E.S., Quintão, N.L.M., Campos, M.M., Calixto, J.B., 2006 Relevance of tumour necrosis factor-a for the inflammatory and nociceptive responses evoked by carrageenan in the mouse paw. British Journal of Pharmacology 148, 688-695.

Schäcke, H., Döcke, W.D., Asadullah, K., 2002. Mechanisms involved in the sideeffects of glucocorticoids. Pharmacology \& Therapeutics 96, 23-43.

Shibata, M., Ohkubo, T., Takahaski, H., Inoki, R., 1989. Modified formalin test: characteristic biphasic pain response. Pain 38, 347-352.

Siqueira-Junior, J.M., Peters, R.R., Brum-Fernandes, A.J., Ribeiro-do-Valle, R.M., 2003. Effects of valeryl salicylate, a cox-1 inhibitor, on models of acute inflammation in mice. Pharmacological Research: The Official Journal of the Italian Pharmacological Society 48, 437-443.

Sugishita, E., Amagaya, S., Ogihara, Y., 1981. Antiinflammatory testing methods: comparative evaluation of mice and rats. Journal of Pharmacobio-dynamics 4 565-575.

Tapiero, H., Ba, G.N., Couvreur, P., Tew, K.D., 2002. Polyunsaturated fatty acids (PUFA) and eicosanoids in human health and pathologies. Biomedicine \& Pharmacotherapy $56,215-222$.

Vane, J.R., 1971. Inhibition of prostaglandin synthesis as a mechanism of action for aspirin-like drugs. Nature: New Biology 231, 232-235.

Vaz, Z.R., Filho, V.C., Yunes, R.A., Calixto, J.B., 1996. Antinociceptive action of 2 (4-bromobenzoyl)-3-methyl-4,6-dimethoxy benzofuran, a novel xanthoxyline derivative on chemical and thermal models of nociception in mice. The Journal of Pharmacology and Experimental Therapeutics 278, 304-312.

Vinger, R., Truax, J.F., Selph, J.L., Jonhston, P.R., Venable, A.L., Mckenzie, R.K., 1987. Pathway to carrageenan-induced inflammation in the hind limb of the rat. Federation Proceedings 46, 118-126.

Winter, C.A., Risley, E.A., Nuss, G.W., 1962. Carrageenan-induced edema in hind paw of the rat as an assay for antiinflammatory drugs. Proceedings of the Society for Experimental Biology and Medicine 111, 544-547.

Zimmermann, M., 1983. Ethical guidelines for investigations of experimental pain in conscious animals. Pain $16,109-110$ 